\title{
FAKTOR - FAKTOR YANG MEMPENGARUHI BOUNDING ATTACHMENT MASA NIFAS
}

\author{
Dewi Susilawati ${ }^{1}$, Nur Fadjri Nilakesuma ${ }^{2}$, Risnawati ${ }^{3}$ \\ Sekolah Tinggi Ilmu Kesehatan Mercubaktijaya Padang ${ }^{1,2}$ \\ Puskesmas Nanggalo Padang ${ }^{3}$ \\ dewisusilawati39@gmail.com ${ }^{1}$
}

\begin{abstract}
ABSTRAK
Tujuan penelitian ini adalah untuk mengetahui faktor-faktor yang mempengaruhi Bounding Attachment masa nifas. Metode penelitian yang digunakan adalah penelitian deskriptif analitik dengan rancangan cross sectional. Hasil penelitian menggambarkan pada variabel karakteristik ibu (umur, pendidikan dan paritas) yang mempengaruhi

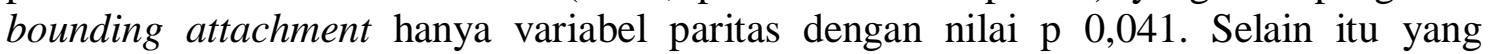
berpengaruh pada bounding attachment adalah variabel respon orang tua/kelaurga ( $\mathrm{p}=$ $0,036)$ dan dukungan social $(\mathrm{p}=0,029)$ sementara itu tidak ada pengaruh tingkat pengetahuan dengan bounding attachment $(\mathrm{p}=1,000)$. Simpulan, lakukan sosialisasi bounding attachment kepada ibu, keluarga, masyarakat sehingga meningkatkan pengetahuan ibu dan meningkatkan keberhasilan bounding attachment antara ibu dan anaknya.
\end{abstract}

Kata Kunci: Bounding Attachment, Ibu Nifas, Postpartum Bonding Questionnaire (PBQ)

\section{ABSTRACT}

The purpose of this study was to determine the factors that affect puerperal breastfeeding attachment. The research method used was descriptive-analytic research with a cross-sectional design. The study results describe the variables of maternal characteristics (age, education, and parity) that affect the bounding attachment, with only parity variables with $p$ values of 0.041. In addition, the effect on bounding attachment is the parent / family response variable $(p=0.036)$ and social support $(p=$ 0.029) while there is no influence of the level of knowledge with bounding attachment ( $p$ $=1,000)$. In conclusion, socialize bounding attachment to mothers, families, the community to increase mother's knowledge and increase the success of Bounding Attachments between mother and child.

Keywords: Bounding Attachment, Postpartum Mother, Postpartum Bonding Questionnaire (PBQ)

\section{PENDAHULUAN}

Bonding adalah daya tarik awal dan dorongan untuk terjadinya ikatan batin antara orang tua dan bayinya sedangkan attachment adalah suatu perubahan perasaan satu sama lain yang paling mendasar ketika ada perasaan keterkaitan tanggung jawab dan kepuasan. Membentuk ikatan batin dengan bayi adalah : proses dimana hasil dari suatu 
interaksi terus-menerus antara bayi dan orang tua (bayi dan anggota keluarga lain) dengan kedua pihak memainkan peran aktif, suatu hubungan yang bersifat saling mencintai dan mantap tercipta dan memberikan keduanya pemenuhan emosional, rasa percaya diri, stabilitas, hubungan yang bersifat saling membutuhkan (meskipun nantinya menjadi kemampuan untuk mandiri/independent dan kapasitas untuk meyadari potensi mereka dalam kehidupan) (Fitriani, Wahyuni, 2017).

Hasil Survei Demografi dan Kesehatan Indonesia (SDKI) tahun 2017 menunjukan AKI sebesar 305/100.000 kelahiran dan AKB di Indonesia sebesar 24/100.000 kelahiran hidup (Kemenkes, 2018). Berdasarkan Profil Kesehatan Provinsi Sumatera Barat tahun 2017, AKI di Sumatera Barat adalah 107/100.000 kelahiran hidup dan 700 orang yang tersebar di 19 Kabupaten/Kota dengan penyumbang tertinggi di Kota Padang sebanyak 111 orang (Sumatera Barat, 2018).

Salah satu untuk mengatasi AKI dan AKB adalah dengan melaksanakan bounding attachment. Ada berbagai cara untuk melakukan bounding attachment diantaranya Inisiasi Menyusu Dini (IMD) dan pemberian ASI eksklusif. Ada beberapa hal yang mempengaruhi proses bounding attachment yaitu kesehatan emosional orangtua; tingkat kemampuan, komunikasi, dan kerampilan untuk merawat anak; Dukungan social seperti keluarga, teman, dan pasangan; kedekatan orang tua dan anak; kesesuaian orang tua dan anak (keadaan anak, jenis kelamin) (Ana, Eti, 2018; Nurhidayati, Mardianingsih, 2018; ; Winarni et al., 2018).

Sebuah studi yang dilakukan oleh Ozluses menunjukkan bahwa pengetahuan ayah atau suami tentang menyusui meningkatkan pemberian ASI eksklusif dan bounding attachment (Shariat, 2017). Hasil penelitian ini juga sama dengan yang dilakukan oleh Anita Rahmawati, bahwa lebih dari setengah jumlah responden mendapatkan dukungan tinggi dari suami atau keluarga yaitu sebanyak 68\%. Menurut Cohen \& Syme, bahwa dukungan suami didefenisikan sebagai dukungan baik secara fisik maupun psikologis yang diberikan suami kepada istrinya, suami atau keluarga ada pada saat dibutuhkan dan dapat memberikan bantuan kepada ibu. Adapun dukungan ini dalam bentuk dukungan emosional, penilaian, informasi dan intrumental (Rahmawati, 2018).

Dukungan sosial juga mempengaruhi bounding attachment terutama dukungan dari suami, dimana hasil penelitian yang dilakukan oleh Winarni tahun 2017 dimana dapat disimpulkan bahwa adanya pengaruh dukungan suami dengan kondisi psikologi ibu postpartum dan jika psikologi ibu tidak ternggagu maka bounding attachment antara ibu dan bayi akan terjalin (Winarni et al., 2018).

Ada beberapa cara untuk melihat keberhasilan suatu bounding attachment salah satunya menggunakan Postpartum Bonding Questionnaire (PBQ). Postpartum Bonding Questionnaire (PBQ) adalah suatu alat yang digunakan untuk menilai hubungan ikatan kasih sayang ibu terhadap anaknya. Jumlah pertanyaan dari Postpartum Bonding Questionnaire (PBQ) adalah sebanyak 25 pertanyaan di hasilnya di bagi menjadi 4 katagori yaitu terjalin hubungan yang baik, ikatan yang rusak, penolakan dan kemarahan patologis, kecemasan yang berfokus pada bayinya (Ghahremani et al., 2019).

Penelitian sebelumnya yang sudah ada hanya tentang bounding attachment saja dan tidak ada yang menggunakan alat ukur ini khususnya di Indonesia. Namun pada penelitian ini menekankan bahwa penggunaan alat ukur yang digunakan, dimana alat ukur yang digunakan adalah Postpartum Bonding Questionnaire (PBQ). Sementara itu alat ukur Postpartum Bonding Questionnaire (PBQ) sangat bagus dalam mengukur 
hubungan ikatan kasih sayang ibu terhadap anak dan variabel yang diteleti lebih lengkap dibandingan artikel2 lain yang membahas tentang bounding attachment.

\section{METODE PENELITIAN}

Jenis penelitian ini adalah deskriptif analitik dengan rancangan Cross Sectional. Sampel penelitian ini Ibu nifas pada bulan Juni - Oktober 2019 yang melakukan kunjungan ke Praktik bidan bersama kurao Wilayah Kerja Puskesmas Nanggalo Kota Padang yaitu sebanyak 70 orang ibu nifas dengan teknik pengambilan sampel adalah accidental sampling. Pengumpulan data dengan cara pengisian kuesioner, dimana koesioner yang digunakan adalah Postpartum Bonding Questionnaire (PBQ). Pengolahan data dengan cara editting, coding, entry, tabulating dan cleaning. Penelitian ini dianalisis dengan uji chi-squar menggunakan aplikasi SPSS16.

Langkah-langkah dan prosedur penelitian ini adalah : 1) mengurus izin penelitian ke Dinas Kesehatan Kota Padang dan Ikatan Bidan Indonesia, 2) setelah izin keluar, peneliti terlebih dahulu mengumpulkan sampel sesuai dengan kriteria penelitian untuk menguji validitas koesiner karena koesioner belum pernah diujikan di Indonesia, 3) menguji validitas koesioner, setelah valid baru peneliti mengambil sampel untuk penelitian ini dengan sampel yang berbeda dengan sampel untuk menguji validitas tersebut tetapi masih sesui dengan kriteria penelitian, 4) sebelum memberikan koesioner pada sampel, peneliti menjelaskan dan meminta kesedian responden barulah koesioner diberikan, 5) setelah sampel terpenuhi baru peneliti mengolah dan menganalisa hasil penelitian tersebut.

\section{HASIL PENELITIAN \\ Pengaruh Karakteristik Ibu terhadap Bonding Attachment Umur}

Tabel. 1

Pengaruh Umur Ibu terhadap Bounding Attachment Masa Nifas

\begin{tabular}{|c|c|c|c|c|c|c|c|c|}
\hline \multirow[t]{3}{*}{ No } & \multirow[t]{3}{*}{ Umur } & \multicolumn{4}{|c|}{ Bounding Attachment } & \multirow{2}{*}{\multicolumn{2}{|c|}{ Total }} & \multirow{3}{*}{$P$ value } \\
\hline & & \multicolumn{2}{|c|}{ Baik } & \multicolumn{2}{|c|}{ Tidak Baik } & & & \\
\hline & & $\mathrm{f}$ & $\%$ & $\mathrm{~F}$ & $\%$ & $\mathrm{f}$ & $\%$ & \\
\hline 1 & Tidak Bersiko & 42 & 65.6 & 22 & 34.4 & 64 & 100 & \multirow{3}{*}{0.186} \\
\hline 2 & Beresiko & 2 & 33.3 & 4 & 66.7 & 6 & 100 & \\
\hline & Total & 44 & 62.9 & 26 & 37.1 & 70 & 100 & \\
\hline
\end{tabular}

Berdasarkan tabel 1 didapatkan bahwa dari 64 ibu yang memiliki umur tidak beresiko lebih dari setengah memiliki bounding attachment yang baik dengan anaknya dan hampir separuh memiliki bounding attachment yang tidak baik dengan anaknya. Berdasarkan hasil uji statistic dengan uji chi - square didapatkan tidak ada pengaruh umur ibu terhadap bounding attachment masa nifas. 


\section{Pendidikan}

Tabel. 2

Pengaruh Pendidikan Ibu terhadap

Bounding Attachment Masa Nifas

\begin{tabular}{|c|c|c|c|c|c|c|c|c|}
\hline \multirow[t]{3}{*}{ No } & \multirow{3}{*}{$\begin{array}{c}\text { Tingkat } \\
\text { Pendidikan }\end{array}$} & \multicolumn{4}{|c|}{ Bounding Attachment } & \multirow{2}{*}{\multicolumn{2}{|c|}{ Total }} & \multirow{3}{*}{$P$ value } \\
\hline & & \multicolumn{2}{|c|}{ Baik } & \multicolumn{2}{|c|}{ Tidak Baik } & & & \\
\hline & & $\mathrm{f}$ & $\%$ & $\mathrm{~F}$ & $\%$ & $\mathrm{f}$ & $\%$ & \\
\hline 1 & Tinggi & 42 & 63.6 & 24 & 36.4 & 66 & 100 & \multirow{3}{*}{0.624} \\
\hline 2 & Rendah & 2 & 50 & 2 & 50 & 4 & 100 & \\
\hline & Total & 44 & 62.9 & 26 & 37.1 & 70 & 100 & \\
\hline
\end{tabular}

Berdasarkan tabel 2 didapatkan bahwa dari 66 ibu yang memiliki pendidikan tinggi lebih dari setengah memiliki Bounding Attachment yang baik dengan anaknya dan hampir separuh memiliki bounding attachment yang tidak baik dengan anaknya. Berdasarkan hasil uji statistic dengan uji chi-square didapatkan tidak ada pengaruh pendidikan ibu terhadap bounding attachment masa nifas.

\section{Paritas}

Tabel. 3

Pengaruh Paritas Ibu terhadap

Bounding Attachment Masa Nifas

\begin{tabular}{|c|c|c|c|c|c|c|c|c|}
\hline $\mathrm{N}$ & \multirow[t]{3}{*}{ Paritas } & \multicolumn{4}{|c|}{ Bounding Attachment } & \multirow{2}{*}{\multicolumn{2}{|c|}{ Total }} & \multirow{3}{*}{$P$ value } \\
\hline o & & \multicolumn{2}{|c|}{ Baik } & \multicolumn{2}{|c|}{ Tidak Baik } & & & \\
\hline & & $\mathrm{f}$ & $\%$ & $\mathrm{~F}$ & $\%$ & $\mathrm{f}$ & $\%$ & \\
\hline 1 & Tidak Bersiko & 26 & 76.5 & 8 & 35.5 & 34 & 100 & \multirow{3}{*}{0.041} \\
\hline 2 & Beresiko & 18 & 50 & 18 & 50 & 36 & 100 & \\
\hline & Total & 44 & 62.9 & 26 & 37.1 & 70 & 100 & \\
\hline
\end{tabular}

Berdasarkan tabel 3, bahwa dari 34 ibu yang memiliki paritas tidak beresiko didapatkan hampir seluruhnya memiliki bounding attachment yang baik dengan anaknya dan hampir separuh memiliki bounding attachment yang tidak baik dengan anaknya. Berdasarkan hasil uji statistic dengan uji chi-square didapatkan ada pengaruh paritas ibu terhadap bounding attachment masa nifas.

\section{Pengaruh Respon Orang Tua/Keluarga terhadap Bonding Attachment}

Tabel. 4

Pengaruh Respon Orang Tua/Keluarga terhadap

Bounding Attachment Masa Nifas

\begin{tabular}{|c|c|c|c|c|c|c|c|c|}
\hline \multirow[t]{3}{*}{ No } & \multirow{3}{*}{$\begin{array}{l}\text { Respon Orang } \\
\text { Tua/Keluarga }\end{array}$} & \multicolumn{4}{|c|}{ Bounding Attachment } & \multirow{2}{*}{\multicolumn{2}{|c|}{ Total }} & \multirow{3}{*}{$P$ value } \\
\hline & & \multicolumn{2}{|c|}{ Baik } & \multicolumn{2}{|c|}{ Tidak Baik } & & & \\
\hline & & $\mathrm{f}$ & $\%$ & $\mathrm{~F}$ & $\%$ & $\mathrm{f}$ & $\%$ & \\
\hline 1 & Positif & 28 & 75.7 & 9 & 24.3 & 37 & 100 & \multirow{3}{*}{0.036} \\
\hline 2 & Negatif & 16 & 48.5 & 17 & 51.5 & 33 & 100 & \\
\hline & Total & 44 & 62.9 & 26 & 37.1 & 70 & 100 & \\
\hline
\end{tabular}

Berdasarkan tabel 4 didapatkan bahwa dari 37 ibu yang mendapatkan respon positif dari orang tua / keluarga hampir semuanya mengalami bounding attachment yang baik sedangkan yang tidak baik hanya sebagian kecil. Berdasarkan hasil statistik 
statistic dengan uji chi-square didapatkan pengaruh respon orang tua/keluarga terhadap bounding attachment masa nifas.

\section{Pengaruh Dukungan Sosial terhadap Bonding Attachment}

Tabel. 5

Pengaruh Dukungan Sosial terhadap

Bounding Attachment Masa Nifas

\begin{tabular}{|c|c|c|c|c|c|c|c|c|}
\hline $\mathrm{N}$ & \multirow[t]{3}{*}{ Dukungan Sosial } & \multicolumn{4}{|c|}{ Bounding Attachment } & \multirow{2}{*}{\multicolumn{2}{|c|}{ Total }} & \multirow{3}{*}{$\mathrm{P}$ value } \\
\hline $\mathrm{o}$ & & \multicolumn{2}{|c|}{ Baik } & \multicolumn{2}{|c|}{ Tidak Baik } & & & \\
\hline & & $\mathrm{F}$ & $\%$ & f & $\%$ & $\mathrm{f}$ & $\%$ & \\
\hline 1 & Positif & 25 & 78.1 & 7 & 21.9 & 32 & 100 & \multirow{3}{*}{0.029} \\
\hline 2 & Negatif & 19 & 50 & 19 & 50 & 38 & 100 & \\
\hline & Total & 44 & 62.9 & 26 & 37.1 & 70 & 100 & \\
\hline
\end{tabular}

Berdasarkan tabel 5 didapatkan bahwa dari 32 ibu yang mendapatkan dukungan positif dari lingkungan sosialnya hampir seluruhnya yang mengalami bounding attachment baik sedangkan yang tidak baik hanya sebagian kecil. Berdasarkan hasil statistik statistic dengan uji chi-square didapatkan adanya pengaruh dukungan social terhadap bounding attachment masa.

\section{Pengaruh Tingkat Pengetahuan terhadap Bonding Attachment}

Tabe. 6

Pengaruh Tingkat Pengetahuan terhadap

Bounding Attachment Masa Nifas

\begin{tabular}{|c|c|c|c|c|c|c|c|c|}
\hline \multirow[t]{3}{*}{ No } & \multirow{3}{*}{$\begin{array}{c}\text { Tingkat } \\
\text { Pengetahuan }\end{array}$} & \multicolumn{4}{|c|}{ Bounding Attachment } & \multirow{2}{*}{\multicolumn{2}{|c|}{ Total }} & \multirow{3}{*}{$\mathrm{P}$ value } \\
\hline & & \multicolumn{2}{|c|}{ Baik } & \multicolumn{2}{|c|}{ Tidak Baik } & & & \\
\hline & & $\mathrm{F}$ & $\%$ & $f$ & $\%$ & $\mathrm{f}$ & $\%$ & \\
\hline 1 & Tinggi & 37 & 62.7 & 22 & 37.3 & 59 & 100 & \multirow{3}{*}{1,000} \\
\hline 2 & Rendah & 7 & 63.6 & 4 & 36.4 & 11 & 100 & \\
\hline & Total & 44 & 62.9 & 26 & 37.1 & 70 & 100 & \\
\hline
\end{tabular}

Berdasarkan tabel 6 didapatkan bahwa dari 59 ibu yang memiliki tingkat pengetahuannnya tinggi lebih dari separuh ib yang mengalami bounding attachment yang baik sedangkan yang tidak baik hampir separuh ibu. Berdasarkan hasil statistik statistic dengan uji chi-square didapatkan tidak adanya pengaruh tingkat pengetahuan ibu terhadap bounding attachment masa nifas.

\section{PEMBAHASAN}

\section{Pengaruh Karakteristik Ibu terhadap Bonding Attachment Umur}

Berdasarkan tabel 1 didapatkan nilai p 0.186, yang artinya tidak ada pengaruh umur ibu terhadap bounding attachment masa nifas karena nilai $\mathrm{p}$ valuenya lebih besar dari pada 0,05 .

Walaupun hasil statistik tidak ada hubungan antara umur dengan bounding attachment namun, data dapat memperlihatkan bahwa umur yang tidak beresiko hanya sebagian kecil yang mengalami bounding attachment yang tidak baik $(33,4 \%)$ begitu juga umur yang beresiko hanya sebagian kecil yang mengalami bounding attachment yang baik $(33,3 \%)$. 
Dari hasil penelitian ini juga dapat dilihat umur tidak di pengaruhi mungkin disebabkan karena ibu yang memiliki umur tidak beresiko memiliki paritas yang tidak beresiko $(97,1 \%)$, mendapat respon orangtua/ keluarga yang positif sebanyak $(89,2 \%)$, mendapat dukungan sosial yang positif $(90,6 \%)$ dan memiliki pengetahuan tinggi $(91,5 \%)$ makanya karena faktor-faktor ini yang menyebabkan umur tidak mempengaruhi baunding attachment pada penelitian ini.

Usia mempengaruhi terhadap cara pandang seseorang dalam menghadapi suatu hal dalam kehidupan, proses perkembangan seseorang ditentukan oleh usia yang kemungkinan telah memiliki berbagai pengalaman dalam kehidupan termasuk dalam pengelolaan keadaan psikologisnya. Pada kelompok usia kurang dari 20 tahun organorgan reproduksinya belum matang, psikis wanita untuk jadi ibu pada usia ini belum siap menghadapi kehamilan, persalinan dan nifas. Masa ini merupakan masa yang rentan karena pada tahap ini seseorang individu akan mengalami suatu perubahan baik secara fisik maupun psikologi, yang mana jika individu tersebut tidak mampu beradaptasi maka akan menimbilkan gangguan dalam bentuk stress maupun penyimpangan yang lainnya (Nurhidayati, Mardianingsih, 2018).

Banyak faktor yang mempengaruhi proses bounding attachment yaitu kesehatan emosional orangtua; tingkat kemampuan, komunikasi, dan kerampilan untuk merawat anak; Dukungan sosial seperti keluarga, teman, dan pasangan; kedekatan orang tua dan anak; kesesuaian orang tua dan anak (keadaan anak, jenis kelamin) ( Rahmawati, 2018; Shariat, Abedinia, 2017; Winarni et al., 2018).

\section{Pendidikan}

Walaupun hasil statistik tidak ada hubungan antara pendidikan dengan bounding attachment namun, data dapat memperlihatkan bahwa hanya sebagian kecil ibu yang berpengetahuan tinggi yang mengalami bounding attachment yang tidak baik yaitu sebanyak $36,4 \%$ begitu juga sebaliknya hanya setangah ibu yang memiliki pendidikan rendah yang mengalami bounding attachment yang baik yaitu sebanyak $50 \%$.

Hasil penelitian ini sama yang dilakukan Ana, Eti (2018) menunjukkan bahwa lebih separuh ibu memiliki pengetahuan tinggi. ibu yang memiliki pengetahuan tinggi umumnya akan menerima perubahan dalam hal dalam pemeliharaan kesehatan didalam penelitian ini juga menjelaskan bahwa ibu nifas yang memiliki pendidikan tinggi akan memperkaya dirinya dengan ilmu-ilmu yang berguna dalam perawatan bayi baru lahir. Maka dari itu ibu yang memiliki pengetahuan tinggi banyak yang memiliki hubungan yang baik dengan anaknya.

Hasil penelitian ini juga dapat dilihat banyak faktor yang mempengaruhi bounding attachment sehingga menyebabkan pendidikan tidak mempengaruhi bounding attachment ini disebabkan karena pada ibu yang memiliki pengetahuan tinggi memilki paritas yang tidak beresiko sebanyak $91,2 \%$, respon positif dari orang tua/keluarga sebanyak 97,3\%, mendapat dukungan positif sebanyak $100 \%$ dan memiliki pengetahuan tinggi sebanyak $96.6 \%$.

\section{Paritas}

Dalam penelitia ini variabel ibu yang beresiko adalah ibu yang memiliki paritas 1 dan $>3$ sedangkan variabel tidak beresiko adalah ibu yang memiliki paritas 2 dan 3 . Wanita primipara lebih mudah stress pada masa nifas. Hal ini bisa terjadi karena setelah melahirkan untuk pertama kali akan mengalai proses adaptasi terhadap perubahan adaptasi dari berbagai macam perubahan terutama psikologinya. Salah satunya adalah 
adaptasi wanita terhadap peran baru yang harus dia emban yaitu menjadi seorang ibu. Bagi wanita primipara, peran ini adalah peran baru yang belum ia pahami bentuk dan cara yang benar dalam menjalaninya sementara itu bayinya harus tetap dirawat. Begitu juga dengan ibu yang sudah memiliki anak lebih dari 3 atau yang disebeut dengan grademultipara. Ibu yang memiliki paritas grande multipara memiliki pengalaman yang banyak dalam hal perawatan anak tetapi pada saat ibu dia juga akan mengalami kesulitan dalam hal merawat bayinya. selain dia merawat bayinya dia juga harus merawat anak-anaknya yang lain.

Hasil penelitian ini sama yang dilakukan oleh Ilham Paramastyia didapatkan hasil bahwa ibu dengan status primipara atau yang memiliki paritas satu lebih banyak mengalami baby blues syndrome dibandingkan multipara (Paramasatya, 2018). ibu yang mengalami baby blues syndrome akan mempengaruhi bounding attachment antara ibu dan bayi.

\section{Pengaruh Respon Orang Tua/Keluarga terhadap Bonding Attachment}

Orang tua yang mengharapkan kehadiran si anak dalam kehidupannya tentu akan memberikan respon emosi yang berbeda dengan orang tua yang tidak menginginkan kelahiran bayi tersebut. Respon emosi yang positif dapat membantu tercapainya proses bounding attachment (Nurhidayati, Mardianingsih, 2018).

Penelitian yang dilakukan oleh Palsson bahwa kedua orang tua mengharapkan dan menuntut peningkatan keterlibatan ayah selama kehamilan, kelahiran dan menjadi orang tua awal. Interaksi teratur dan sejak dini yang dilakukan pasangan terutama ayah dengan bayi dan membuat keterikatan hubungan yang sangat kuat untuk bekal pembentukan mental anak. Keterlibatan ayah dalam menciptakan hubungan baik dengan bayi tidak hanya dengan cara memberikan dukungan kepada ibu saja tetapi para ayah juga harus memiliki peran aktif dalam melakukan perawatan pada anaknya. Selain itu untuk menjaga hubungan ibu dan anak tetap baik, peran ayah disini adalah dengan memberikan kompensasi waktu bagi ibu contohnya dengan membantu ibu dalam melakukan tugas-tugas dirumah sehingga ibu merasakan diperhatikan (Pålsson et al., 2017).

Melaksanakan peran ayah dalam menciptakan hubungan yang baik dengan bayinya ini dipengaruhi oleh emosi, dukungan bidan sehingga menciptakan kepercayaan diri bagi mereka. Ini dampaknya menjadi dasar untuk mengambil tanggung jawab selama hari-hari pertama dirumah. Ketika seorang ayah terlibat dalam perilaku pengasuhan berkualitas tinggi, bounding attanchment dapat berkembang bahkan ketika ayah menghabiskan waktu relatif sedikit dengan anak begitu juga sebaliknya (Brunstad et al., 2018).

Hasil penelitian ini juga sama dengan yang dilakukan oleh Rahmawati yang menunjukkan bahwa lebih dari setengah jumlah responden mendapatkan dukungan tinggi dari suami atau keluarga yaitu sebanyak 68\%. Menurut Cohen \& Syme, bahwa dukungan suami didefenisikan sebagai dukungan baik secara fisik mapupun psikologis yang diberikan suami kepada istrinya, suami atau keluarga ada pada saat dibutuhkan dan dapat memberikan bantuan kepada ibu. Adapun dukungan ini dalam bentuk dukungan emosional, penilaian, informasi dan intrumental (Rahmawati, 2018). 


\section{Pengaruh Dukungan Sosial terhadap Bonding Attachment}

Berdasarkan tabel 5 didapatkan bahwa dari 32 ibu yang mendapatkan dukungan positif dari lingkungan sosialnya yang mengalami bounding attachment nya baik adalah sebanyak 25 (78.1\%) sedangkan yang tidak baik sebanyak 7 (21.9\%). Berdasarkan hasil statistik statistic dengan uji chi-square didapatkan nilai p 0.029 artinya adalah adanya pengaruh dukungan social terhadap Bounding attachment masa nifas karena nilai $\mathrm{p}$ valuenya kurang dari 0,05 .

Dukungan social juga mempengaruhi bounding attachment terutama dukungan dari suami, dimana hasil penelitian yang dilakukan oleh Winarni tahun 2017 dimana dapat disimpulkan bahwa adanya pengaruh dukungan suami dengan kondisi psikologi ibu postpartum dan jika psikologi ibu tidak terganggu maka bounding attachment antara ibu dan bayi akan terjalin (Winarni et al., 2018).

Hasil penelitian menunjukkan bahwa pada ibu dengan tingkat dukungan sosialnya tinggi memiliki resiko depresi postpartum yang rendah. hubungan positif antara dukungan sosial dengan kesehatan. Dukungan dari keluarga, teman, terutama pasangan merupakan faktor yang juga penting untuk diperhatikan karena dengan adanya dukungan dari orang-orang terdekat akan memberikan suatu semangat / dorongan positif yang kuat bagi ibu untuk memberikan kasih sayang yang penuh kepada bayinya (Vaezi et al., 2019).

Kejadian baby blus dapat berkembang menjadi depresi post partum. Depresi post partum ini memberikan dampak negatif terhadap pelaksanaan bounding attachment. Secara klinis, ibu yang mengalami depresi akan kurang dalam memberikan kasih sayang terhadap anak-anak mereka, sehingga menyebabkan perasaan rasa bersalah atau tidak berharga, dan mereka sering merasa cemas. Hal ini akan membuat si ibu melakukan kerusakan psikologis atau fisik kepada anak-anak mereka (Brazeau et al., 2018).

Hasil penelitian yang dikukan oleh Nurfatimah dimana didaptkan ibu yang kurang mendapatkan dukungan sosial lebih banyak mengalami depresi postpartum. Jika ibu mengalam depersi postpartum dapat mempengaruhi hubungan atau bounding attachmen antara ibu dan bayinya. Dukungan memberikan pengaruh dalam mengurangi depresi yang dihadapi wanita pada masa nifas (Nurfatimah, Enton, 2018).

Dukungan sosial terutama dari orang tua ataupun keluarga sangat dibutuhkan oleh ibu terutama pada minggu-minggu pertama postpatum, terutama oleh ibu yang memiliki paritas satu atau primigravida dimana belum memiliki pengalaman yang cukup dalam hal perawatan bayi baru lahir, karena pada masa ini keadaan ibu masih lemah sehingga membutuhkan bantuan dari keluarganya (Nurfatimah, Enton, 2018).

\section{Pengaruh Tingkat Pengetahuan terhadap Bonding Attachment}

Berdasarkan tabel 6 didapatkan bahwa dari 59 ibu yang memiliki tingkat pengetahuannnya tinggi yang mengalami bounding attachment yang baik adalah sebanyak 37 (62.7\%) sedangkan yang tidak baik adalah sebanyak 22 (37,3\%) ibu. Berdasarkan hasil statistik statistic dengan uji chi-square didapatkan nilai p valuenya adalah 1.000 dimana artinya adalah tidak adanya pengaruh tingkat pengetahuan ibu terhadap bounding attachment masa nifas karena nilai p valuenya lebih dari 0,05.

Hasil penelitian ini sama yang dilakukan oleh Ana dan Eti pada tahun 2018, menunjukkan bahwa lebih dari setengan ibu nifas memiliki pengetahuan baik tentang bounding attachment, dalam penelitian ini juga mengatakan bahwa ibu nifas yang memiliki pengetahuan baik akan melakukan bounding attachmen yang baik (Ana, Eti, 2018). 
Salah satu penyebab tidak adanya pengaruh pengetahuan terhadap bounding attachment pada penelitian ini adalah hanya sebagian kecil responden (37\%) yang tahu tentang sibling rivalry. Sibling rivalry merupakan persaingan antar saudara untuk memperebutkan perhatian dan kasih sayang orang tua. Idealnya persaingan ini harus dapat dihindari dan diantisipasi oleh orang tua, karena dapat menghambat terbentuknya bounding attachment yang baik. Ibu beranggapan bahwa membanding-bandingkan anak yang satu dengan yang lainnya adalah hal yang tepat agar anak bisa menjadi lebih baik lagi baik itu dalam bersikap maupun dalam prestasi di sekolah. Ibu harus mengetahui tentang hal-hal negatif yang dilakukan oleh anak kepada kakak maupun adiknya baik di rumah maupun di sekolah karena tanpa ibu sadari bisa saja anak sedang mengalami sibling rivalry (Andriyani, Darmawan, 2018).

Pengetahuan dapat menggambarkan wawasan seseorang yang dipengaruhi oleh tingkat pendidikan, dimana tingkat pendidikan tersebut berpengaruh terhadap penerimaan atau pemahaman serta daya ingat seseorang terhadap informasi yang pernah diperoleh. Orang yang berpendidikan tinggi akan memberikan respon yang lebih rasional terhadap informasi yang datang dan akan berpikir sejauh mana keuntungan yang akan didapatkannya. Semakin tinggi pendidikan seseorang semakin mudah pula mereka menerima informasi, dan pada akhirnya semakin banyak pula pengetahuan yang dimilikinya. Sebaliknya jika seseorang tingkat pendidikannya rendah, maka akan menghambat perkembangan sikap seseorang terhadap penerimaan informasi dan nilainilai yang baru diperkenalkan.

Namun, hasil penelitian yang ditemukan bertolak belakang dengan teori diatas. Tingkat pendidikan responden tergolong tinggi, namun belum mampu melaksanakan bounding attachment dengan baik. Hal ini dapat disebabkan oleh belum mampunya ibu mengontrol emosi saat berhadapan dengan bayinya. Keadaan ini terlihat dari kuisioner dimana ibu banyak menjawab tidak mampu untuk mengontrol emosi saat berhubungan dengan bayi.

\section{SIMPULAN}

Adanya pengaruh antara paritas, respon orang tua dan dukungan sosial terhadap bounding attachment.

\section{SARAN}

Saran penelitian ini adalah bidan sebaiknya melakukan sosialisasi bounding attachment kepada ibu, keluarga, masyarakat bisa meningkatkan pengetahuan ibu dan meningkatkan keberhasilan bounding attachment antara ibu dan anaknya.

\section{DAFTAR PUSTAKA}

Ana, F., \& Eti, S. (2018). Gambaran Pengetahuan dan Sikap Ibu Nifas Tentang Bounding Attachment di Ruangan Seruni Rumah Sakit PMI Kota Bogor. Jurnal Riset Kesehatan Poltekkes Depkes Bandung, 10(2), 23-30. https://doi.org/10.34011/juriskesbdg.v10i2.207

Andriyani, S., \& Darmawan, D. (2018). Pengetahuan Ibu tentang Sibling Rivalry pada Anak Usia 5 - 11 Tahun di Cisarua Kabupaten Bandung Barat. Jurnal Pendidikan Keperawatan Indonesia, 4(2), 162-171. https://doi.org/10.17509/jpki.v4i2.13708

Brazeau, N., Reisz, S., Jacobvitz, D., \& George, C. (2018). Understanding the Connection Between Attachment Trauma and Maternal Self-Efficacy in Depressed Mothers. Infant Mental Health Journal, 39(1), 30-43. 
https://doi.org/10.1002/imhj.21692

Brunstad, A., Aasekjær, K., Aune, I., \& Nilsen, A. B. V. (2018). Fathers' Experiences During the First Postnatal Week at Home After Early Discharge of Mother and Baby from the Maternity Unit: A Meta-Synthesis. Scandinavian Journal of Public Health, August. https://doi.org/10.1177/1403494818809856

Fitriani, L., \& Wahyuni, S. (2017). Hubungan Pelaksanaan Bounding Attchment pada Ibu Primipara dengan Reaksi Ibu dan Bayi di Kamar Bersalin RSUD Polewali Mandar. 2017

Ghahremani, S., Aryan, H., Ghahremani, S., \& Rakhshanizadeh, F. (2019). Factorial Structures of Postpartum Bonding Questionnaire ( PBQ ): A Systematic Review. Int J Pediatri, 7(64), 9295-9303. https://doi.org/10.22038/ijp.2018.36262.3164

Kemenkes, RI. (2018). Data Dan Informasi Profil Kesehtan Indonesia 2017

Nurfatimah, N., \& Enton, C. (2018). Hubungan Faktor Demografi Dukungan Sosial dengan Depresi Pasca Salin. Jurnal Profesi Medika, 11(2), 89-99. https://doi.org/10.1017/CBO9781107415324.004

Nurhidayati, N., \& Mardianingsih. (2018). Keberhasilan Bounding Attachment melalui Proses Inisiasi Menyusui Dini. Jurnal Kebidanan, 10(2), 153-161

Pålsson, P., Persson, E. K., Ekelin, M., Kristensson, H. I., \& Kvist, L. J. (2017). FirstTime Fathers Experiences of Their Prenatal Preparation in Relation to Challenges Met in the Early Parenthood Period: Implications for Early Parenthood Preparation. Midwifery, 50(March), 86-92. https://doi.org/10.1016/j.midw.2017.03.021

Paramasatya, I. (2018). Hubungan antara Usia dan Paritas dengan Kejadian Baby Blues Syndrome [Universitas Muhammadiyah Surakarta]. https://doi.org/10.1109/COMST.2015.2457491

Rahmawati, A. (2018). Hubungan Dukungan Suami dengan Bounding Attachment pada Ibu Post Partum di RSUD Kota Jombang. JUrnal Kesehatan Insan Cedikia Medika, 15(1), 66-72. https://doi.org/10.1145/2505515.2507827

Shariat, M., \& Abedinia, N. (2017). The Effect of Psychological Intervention on Mother-Infant Bonding and Breastfeeding. Iranian Journal of Neonatology, 8(1), 7-15. https://doi.org/10.22038/ijn.2017.16673.1191

Sumatera Barat, D. K. (2018). Profil Kesehatan Provinsi Sumatera Barat 2017

Vaezi, A., Soojoodi, F., Banihashemi, A. T., \& Nojomi, M. (2019). The Association Between Social Support and Postpartum Depression in Women: A Cross Sectional Study. Women and Birth, 32(2), e238-e242. https://doi.org/10.1016/j.wombi.2018.07.014

Winarni, L. M., Einarni, E., \& Ikhlasiah, M. (2018). Pengaruh Dukungan Suami dan Bounding Attachment dengan Kondisi Psikologis Ibu Postpartum di RSUD Kabupaten Tangerang Tahun 2017. Jurnal Ilmiah Bidan, 3(2), 1-11 